\title{
Bilinguals and Monolinguals' Performance in English Language Learning in Nigeria
}

\author{
Abolaji Samuel Mustapha \\ Departrment of English, Lagos State University, Ojo, Lagos, Nigeria/Sheffield Hallam University, UK \\ E-mail: abolajimustapha@hotmail.com
}

Received: March 12, 2012

Accepted: May 24, 2012

Online Published: June 5, 2012

doi:10.5430/elr.v1n1p78

URL: http://dx.doi.org/10.5430/elr.v1n1p78

Acknowledgements: This paper was first jointly presented by the author and his research assistant, Bola Ajani, at the 2011 ELTT Conference in Nigeria and a shorter version is forthcoming in ELTT Journal.

\begin{abstract}
Some linguists argue that bilinguals' knowledge and competence in their first language contribute to effective second language learning. On the contrary, other linguists who favour monolingualism hold that the first language stands as an obstacle for bilinguals. These opposing views motivated the present undertaking. Thus this study investigates the performance of both bilingual and monolingual learners' of English Language in a second language situation in Nigeria. Terminal results in English Language tests of 108 Yoruba/English bilinguals and 108 Nigerian English monolinguals at the Senior Secondary School level were compared. Findings revealed that, on the one hand, more bilinguals are found in the pass region than monolinguals; on the other hand, more monolinguals were found in the fail region than bilinguals. These results confirm the position that bilingualism plays supportive role in second language learning, especially in second language situation. Consequently, stakeholders in second language learning might need to strengthen the learning and use of bilinguals' first language in order to enhance effective second language learning.
\end{abstract}

Keywords: Bilinguals, Monolinguals, English, Performance, Learners, Nigeria

\section{Introduction}

The debate on whether sound and serious study of the first language is fundamental to cognitive, affective and social development of L2 learners and their level of proficiency and better performance in the second language has preoccupied applied linguists, especially in multilingual societies for some decades. The debate has divided linguists into two camps. While one school of thought holds that the first language of bilinguals is detrimental to learners' proficiency in the second language (Cummins, 1994; Laubeova, 2000 among others), the other school argues that the opposite is the case - being a bilingual puts the learner in a better position in second language learning (Trifonovitch, 1981; Aduwa, 2006 among others). In this study, an empirical investigation is undertaken among some secondary school students in Nigeria to support and/or refute the claims. The results of the English Language tests (that examine learner's spoken English, essay and letter writing skills; and their grasp of grammar and usage, idioms, meaning relations, lexis and structures in English) administered to bilinguals and monolinguals are used. In other words, bilinguals' scores and monolinguals' in the tests are compared.

\section{Background}

\subsection{Negative role of first language to second language learning}

Trifonovitch (1981) opined that first language acquisition is detrimental to second language learning. This factor has been referred to in the literature as the substrate influence on language learning. According to Trifonovitch (1981) (cited in Aduwa, 2006), a student is automatically placed at a disadvantage when he/she already has a language of her/his own and he/she is asked to learn another language. The claim is that majority of secondary school students in Nigeria already have various mother tongues before they are admitted into schools which put them at a disadvantage. For example, negative transfer from the first language has been identified as one of the militating factors that hamper the learning of the second language. In other words, features of the first language interfere in the use of the second language - the learner uses the L2 in the light of the grammar of the first language. This is referred to in the literature as language interference. Thus it has been concluded that when learning the second language, users tend to 
indiscriminately transfer many of the characteristics of their first language into the second language or the target language thereby hampering their performance in the target language. Brown (1997) calls this interlingual transfer. It has been added that such transfers may also arise from other languages around the learner (Schmied, 1999).

An extreme position of this school of thought is that learning a second language may lead to what has been described as subtractive bilingualism. The case of subtractive bilingualism is that in which the second language is added to the language repertoire of a bilingual at the expense of the first language (partial loss of competence in the first language). In other words, competence and performance in the first language diminish as a result of the exposure to the second language. In other words, a learner is automatically placed at a disadvantage when he/she already has a language of his or her own and he or she is asked to learn another language. This is akin to the controversial concept of 'semilingualism', a state where the second language learner is neither competent in his or her first language nor in the second language. In other words, semilingualism might be described as a state of interruption of L1 development and partial L2 development or as Skutnabb-Kangas (1981) put it - a pejorative term used to describe bilingual individuals who display the following characteristics in both languages: a small vocabulary, incorrect grammar, must consciously think about language production, stilted and uncreative with each language, and difficulty thinking and expressing emotions in both languages.

\subsection{Positive role of first language to second language learning}

On the other hand, some linguists opine that bilingual learners (learners who have acquired a first language before learning a second language) of second language have greater mental flexibility and are superior in abstract thinking than monolingual learners of a second language who have not acquired their (first) indigenous language. It has been argued in the literature that this factor (possessing first language system before learning another (a second language) among others enables bilinguals to perform better than monolinguals in tests of intelligence and in performance in the second language. In other words, when a learner who has acquired a first language comes on to learn a second language, the knowledge of the first language enhances the learning of the second. This creates an additive bilingual situation. Laubeova (2000) describes additive bilingualism as the acquisition of a second language without any loss or weakening of the first language, that is, a learner's first language is valued and recognized in the face of the development of the second language which, in fact, makes the second language learning more effective. Thus, some scholars hold that learners working in an additive bilingual environment succeed to a greater extent than those whose first language and cultures are devalued by their schools and the wider society (Cummins, 1994; Romaine, 1994). Therefore, high proficiency in the first language enables a bilingual to perform better in the second language - additive bilingualism. Additive bilingualism is used in the sense that learning a second language puts the learner in an advantageous position as opposed to subtractive bilingualism which puts learners at a disadvantage. In fact, some linguists claim that a second language learner is automatically placed at an advantage when he/she already has a first language.

A number of studies have thrown their weight behind the latter claim. For example, Thomas and Collier (1997) stress that both cognitive and affective development in the L1 have been found to have positive effects on second language learning and that students with little or no academic and cognitive development in their first language fail to maintain positive gain. Therefore maximum educational benefit from bilingualism is possible only when children are trained to a level where they are stable bilinguals, that is threshold level where competence and performance (in oral and written communication; casual and formal communication) in the first language is comparable to that in the second language. What this means is that if their competence and performance in the first language are inadequate or deficient, there will be no advantage when the second language is introduced. Kembo-Sure (2000) noted that cognitive and development occurs more effectively in language learners know very well $(\mathrm{p}, 89)$. This means that learning a second language occurs more effectively if the required cognitive development has already occurred through the use of a first language as a language of learning. In addition, it has been reported that learning to read and write in the first language supports success with reading and writing in the second language (August and Halenta, 1997; Robert, 1994). The knowledge and experiences from the first language of the second language learner should therefore, be used and built upon to promote the learning of the second language. Thus, Cummins (2000) states that bilingualism has positive effects on children's linguistic and educational development. When children continue to develop their abilities in two languages, they gain a deeper understanding of language and how to use if effectively. They have more practice in processing language, especially when they develop literacy in both, and they are able to compare and contrast the ways in which their two languages organize reality.

Cummins states further that more than 150 research studies conducted during the past 35 years strongly support what Goethe, the German Philosopher once said: "the person who knows only one language does not truly know that 
language". Cummins claims that the development of children's mother tongue is a strong predictor of their second language development - children who come to school with a solid foundation in their first language develop stronger literacy abilities in the second language. On the other hand, children, who come to school with a weak foundation in their mother tongue development, will find it difficult in mastering second language skills.

\subsection{Language situation in Nigeria and English language learning}

Nigeria has well over 400 indigenous languages (Bamgbose, 1992) and by its language policy has English and French as official languages with three local languages - Hausa, Yoruba and Igbo serving as auxiliary official languages (Adeniran, 1995; Bamgbose, 1992;Oyetade, 2003). As a nation that promotes societal bilingualism, its citizens are expected to be literate in English and/or French, in an indigenous language and one other indigenous language preferably from Yoruba, Igbo and Hausa. Thus some Nigerians use their first language, English and/or French, one or more of the other indigenous languages. The document on language policy stipulates that every child be taught in the first three years of primary education in indigenous language (language of the immediate environment) while English is taught as a subject. Thereafter, from the fourth year to the secondary education level, English shall be the language of instruction while the indigenous language shall be taught as a school subject. Thus every child is expected to have acquired one indigenous language before commencing formal education.

Generally speaking, many Nigerians are bilinguals - they command more than one language (though the term bilingualism and kinds of bilinguals are controversial and thorny. However, it might be taken that bilingualism exists as a possession of an individual. It is also possible to talk about bilingualism as characteristic of a group or community of people (societal bilingualism) (Baker and Jones, 1998). At the level of individual bilingualism where (a) person(s) learn(s)/acquire(s) more than one without government/communal policy on language use) there are individuals who are either bilinguals or monolinguals. Although we do not have empirical studies on accurate figures of bilinguals and monolinguals in Nigeria because of dearth of studies in the area, but judging from the statistics on educated people in Nigeria which is below $50 \%$, it might be deduced that most Nigerians are monolinguals - users of only their first language(s) (the language of their ethnic group). Thus, it has been claimed that most Nigerians at the individual level are monolinguals although the widespread use of Nigerian Pidgin is expanding the number of bilinguals in the country. We might have more speakers of Nigerian Pidgin/and indigenous language bilinguals than English/indigenous language bilinguals. However, it appears that monolinguals are more than bilinguals. The promotion of mixed marriages where the husband and the wife have two different indigenous languages, imposes family language policy that encourages monolingualism where, the lingua franca, English is used at home and the children become monolinguals except either of the parents or both of them introduced their local languages or the children pick the local language of their immediate community. In fact, many parents encourage their children to be literate in English because of its economic and developmental gains thereby relegating their local languages to the background.

A pedestrian definition of a second language is that of any language learnt after the first language. However, in Nigeria, the English language is considered as the second language not only because it is learnt by many people after acquiring the first language, but because of its status and function thus inviting more learners than any other languages in the country. English is the main official language, the language of formal instruction in schools, the language of religion, of business, the media and others. The history of English in Nigeria has imposed certain functional demands on Nigerians. It is likened to a vehicle for passing information, a vital tool in education, general administration, legal matters, media practice and so on (Banjo,1981; Jowitt, 1991; Tomori, 1981).

In a second language context, an individual already knows his/her mother tongue and it is this language that he/she transfers into the second language. In this situation, two languages constitute the speech repertoire of members. Each of the languages serves specific purposes which could be of educational, commercial reasons and so on. English in Nigeria is also a second language, because speakers of English in Nigeria are members of the outer-circle with their own variety of English that is called Nigerian English.

As mentioned earlier, there are children/learners who are bilinguals and there are others who are monolinguals. Thus in our English language learning environments we have learners who are bilinguals as well as those who are monolinguals - users of English only. Both groups constitute the subjects of our study.

\section{Methods}

\subsection{Participants}

In order to determine whether bilinguals do better than monolinguals in English Language (second learning environment); a comparison was made between the terminal performances of students in English tests from selected secondary schools in Lagos. These are secondary school students between the ages 15-18 years; they had completed 
primary school education and the first three years of secondary school education (junior secondary education) and are now in the last three years of senior secondary education. They have been taught English Language as a school subject at all these levels and have been receiving instruction in English for all the other school subjects aside from subjects on the indigenous language(s). Bilinguals among them are those who have acquired their indigenous language - Yoruba informally and have learnt English formally; while the monolinguals are those who have only been exposed to English both at home and in school. (see the appendix for an example of a monolingual learner) The bilinguals can operate in spoken Yoruba and English fluently while the monolinguals struggle to understand conversations in Yoruba but cannot speak the language. Eighteen selected public senior secondary schools in the Badagry Local Government Area of Lagos State in Nigeria were involved. Their English Language end of term examination results for three academic sessions 2007/08, 2008/9 and 2009/10 are analyzed.

\subsection{Instruments}

Interviews were conducted among the students to determine their language profile - as monolinguals or bilinguals. The bilinguals are literate in Yoruba and English. The monolinguals are literate in English. There were 108 bilinguals and 108 monolinguals randomly selected from the secondary schools. The researcher, a Yoruba/English bilingual conducted the interview and was able to decipher between Yoruba/English bilinguals among the subjects from those who are monolinguals.

Students' results in English Language for three sessions were collected. A school session has three terms. Thus there were eight terms results not nine because the students in the terminal class of the Senior level III do not write the third term exam in their school but write certificate exams of the West African Examination Council.

\subsection{Procedure}

In this section, the analysis of both the pass region and the fail region from the students' end of school term results are presented. The pass region is from $\mathrm{C}-\mathrm{A}$, where $\mathrm{C}$ stands for $50 \%-64 \%$, B1, B2, B3 $65-74 \%$; A - 75+; whereas fail region are scores from $40 \%$ and below. The results presented in the tables below are got from the term results of our subjects, that is, their performance in English Language. Tests in the subject include oral performance, comprehension, essay writing and objective questions testing their spellings, grammar and usage, lexis and structures in English.

(Table 1 should be here, please).

Table 1 shows that there are more bilinguals in the pass region (87.1\%) than monolinguals (68.4\%) considering their average scores for three sessions. Bilinguals' percentage scores in every term in the pass region consistently exceed that of monolinguals. This result is consistent throughout the terms as there is no term when the percentage of monolinguals in the pass region is more than that of bilinguals.

(Table 2 should be here, please)

Table 2 shows that there are more monolinguals (31.6\%) in the fail region than bilinguals (12.9\%) - looking at their scores for three sessions. In fact, the percentage of monolinguals in the fail region almost triples that of bilinguals. While bilinguals' percentage in the fail region for any terms does not exceed $20 \%$, the least percentage for monolinguals in the fail region is $23 \%$ and the highest $41 \%$. Thus, it is interesting to find that there is no term where there are more bilinguals in the fail region than monolinguals. In summary, these results show that bilinguals perform better in second language learning than monolinguals do.

\section{Results and Discussion}

Findings in this study confirm what some studies have reported and tend to suggest that proficiency in the first language enables a bilingual to perform better in the second language. In other words, the first language of a second language learner has positive role to play in the learning of the second language. Similar view has been expressed in the literature. For example, Thomas and Collier (1997) stress that both cognitive and affective development in the L1 have been found to have positive effects on L2 learning whereas learners with little or no academic and cognitive development in their L1 fail to maintain positive gain in the second language. Thus some scholars concluded that maximum educational benefit from bilingualism is possible only when children are trained to a level where they are stable bilinguals, that is threshold level (Cummins, 1984) where competence in the L1 is comparable to that in the L2. In fact, Cummins (1984) has since observed that bilinguals' L1 as an important tool for their better performance in the learning of the L2 consequently advising parents to establish a strong home language policy and provide ample opportunities for children to expand the functions for which they use the L1 (e.g., in reading and writing) and the contexts in which they can use it (e.g., L1 community in day care or playgroups, visits to towns of origin and so on). 
Krashen (1998) lends stronger support for the important role of L2 learners' L1. To Krashen, one acquires language by understanding message and, by obtaining comprehensible input. Therefore, bilinguals' knowledge of their first language affords them general knowledge of the world and subject matter which help to make the English they hear and learn more comprehensible, thereby, resulting in better performance in the learning of the L2 and overall academic performance. Krashen (1998) concluded that literacy in the L1 enhances literacy in the L2 - once a child can read in one language, this knowledge transfers rapidly to any other language he or she learns to read later.

In fact, there are more recent studies that indicate that the above position is yet to be discredited. For example, it has been noted that there is wide agreement among researchers whose work focus on the effects of bi/multilingualism on the learning process that bi/multilingualism facilitates the acquisition of additional language and improves cognitive functioning in individuals. From a language acquisition perspective, we know bilingualism to be positively associated with third language learning and the development of cognitive flexibility (Bialystok, 2004). Reviewing studies in this area, Angelis (2011) observed that in light of all the studies (reviewed), what seems to be clear today is that prior language knowledge is beneficial to the language learning process and that children should be encouraged rather than discouraged to learn languages.

From the cloud of witnesses to the advantageous position bilinguals are placed in second language learning, it has been added that their knowledge of L1 also helps them in other fields of knowledge. For example, Peal and Lambert (1962) (cited in Kembo-Sure, 2000:129) found that bilinguals often perform better in tests of intelligence (IQ Test) than monolinguals. They also found that bilinguals have greater mental flexibility and are superior in abstract thinking and concept formation. In other words, literacy and cognitive skills already acquired in the L1 do not only provide easy transition to second language-medium education but also enhances general academic performance. Thus, Thomas and Collier (1997) corroborate earlier findings when they stressed that both cognitive and affective development in the L1 have been found to have positive effects not only on L2 learning but also on general educational goals.

These studies suggest that teachers and other stakeholders in second language learning/teaching should look for other causes of L2 learners' poor performance in the second language, in this case, English Language rather than attribute their failures to bilingualism. In fact, they should look for ways to strengthen the teaching and learning of bilinguals' first language.

A list of factors affecting the learning of English, aside from first language interference, has been reported in the literature. Amongst them are quality of second language teachers, inappropriate instructional method and materials, lack of conducive teaching and learning environment. Kembo, (2000) noted that the teachers who of necessity function as role models for the second language learners very often have only a limited proficiency in the target language ( $\mathrm{p}$, 293). Obanya (1992) had observed earlier that nearly all the teachers of L2 in her study have no training in contrastive linguistics and therefore were unable to understand and consequently devise effective pedagogical strategies for combating the mostly mother tongue induced kinds of learners' errors that recur in their students' written and oral performance in English. These studies emphasize the need to improve on the competence of teachers of English among second language users of English.

Kembo (2000) stressed the importance of selecting appropriate instructional method in second language teaching since it is an important contributing factor to the general proficiency of L2 learners $(p, 306)$. Where a second language teacher of English is glued to one 'best way' instead of familiarizing him/herself to a variety of instruction delivery method, little or nothing will be achieved. Reyner et al. (2000) noted that many good teachers are adaptive rather than rigid in their approach to teaching children and only loosely base their instruction on a given method (p, 57). A variety of methods should be directed towards developing a communication ability in the L2 where learners will be fully involved in interactional talks and boost learners' ability to use language in real contexts which is usually appropriate, purposeful and coherent (discourse competence). Methods such as the debate, group, audio-lingual and audio-visual and communicative methods that will ensure linguistic competence and discourse competence (communicative competence) should go beyond the use of traditional method of teaching English.

One other factor that has been highlighted in the literature is the provision of conducive teaching and learning environment. Unconducive learning environment, which are created where there are shortage of furniture, insufficient space, poor lighting and insufficient textbooks do not support effective learning (Kembo, 2000). Aduwa (2006) reported that most of the schools in her study are over-crowded especially in public schools with 70 to 100 students in a classroom where the teacher has little or no room at all to give individual attention to learners. In addition, most the schools in her study have no library and where one is available there is scarcity of books. These are areas that should concern stakeholders rather than the unscientific claim that $\mathrm{L} 1$ is responsible for the poor performance. In summary, to 
achieve the desired results in our learners, there is the need to complement the old instructional materials with the modern ones where they are affordable.

\section{Conclusion}

Aside from supporting the view that second learners' first language plays a supportive role in the learning of second language, the findings of this study suggests that more should be done by all the stakeholders to strengthen the learning of bilinguals' first language. The family language policy which weakens the learning and use of first language should be discarded because a weak foundation in their wards' first language will make mastery of L2 skills difficult. Whereas, a strong foundation in the first language enables second language learners to transfer their knowledge and skills across languages especially to the L2. It has been claimed that languages nurture one another when the educational environment permits children access to various languages. An example that has been cited in the literature says that when children are learning through a minority language (L1) they are not only learning this language in a narrow sense they are learning concepts and intellectual skills that are equally relevant to their ability to function in the majority language (L2). The advice that parents should establish a strong home language policy and provide ample opportunities for children to expand the function for which they use the L1 is not appropriate but must the seconded by creating an additive bilingualism situation where the first culture continues to be valued while the second language is added; this is contrary to the subtractive bilingualism situation where the second language is added at the expense of the first language culture. An understanding of the distinction between additive and subtractive bilingualism should arm language teachers with methods and measures that will ensure that the learning/acquisition of a second language does not lead to any loss or weakening of the first language. That may demand for programmes/activities that would help learners to recognize, value, develop and use their first language thereby ensuring the development of the second language. This would avert edging out the first language from the classroom and school environments.

Since many scholars hold the view that students working in an additive bilingual environment succeed to a greater extent than those whose first language and culture are devalued by their schools and by the wider society stakeholders in bilingual education communities must strike the balance. Thus second language teachers are urged to do all they can to demonstrate to non-native English students that their cultures and languages are equally as valid and valued as the English language. As it has been noted elsewhere, it is reiterated here that L2 teachers should explore every possibility to incorporate the different cultural background of the students into their daily teaching and curricula. Since "proficiency in the L1 does not only aids better performances in the L2 but also helps in the continuing development of the L1 which has a positive influence on cognitive development, has practical advantages, and promotes a healthy sense of biculturalism" all the stakeholders in the learning of second language - English Language should put in place mechanism that will promote the learning and use of bilinguals' first language before formal school age and during the years of learning and in the larger society. From our study, it appears that bilinguals' first language does not hamper but help the learning of the second language, consequently, it should be valued, promoted and used as a supportive factor in a healthy additive bilingual situation.

\section{References}

Adeniran, A. (1995). Language education provisions in Nigeria's National Policy on Education: A critique. In K.

Owolabi (Ed.) Language in Nigeria: Essays in Honour of Ayo Bamgbose. (pp 189-200). Ibadan: Group Publishers.

Aduwa, S. (2006). Factors Affecting Quality of English Language Teaching and Learning in Secondary Schools in Nigeria. [Online] Available: http://www.learnfaster.org/English/ESL_EFL_Teachers/Factors_affecting_quality_of English (September 3, 2010).

Angelis, G. D. (2011). Teachers' belief about the role of prior language knowledge in language learning and how these influence teaching practices. International Journal of Multilingualism 8/3:216-234. http://dx.doi.org/10.1080/14790718.2011.560669

August and Halenta (1997). Second Language learning. [Online] Available: http://www.ncrel.org/sdrs/areas/issues/content/cntareas/reading/li7lk12.htm. (February 4, 2010).

Bamgbose, A. 1992. Speaking in Tongues: Implications of Multilingualism for Language Policy in Nigeria. Nigerian National Merit Award Winners' Lecture, Kaduna.

Bamgbose, A. (1995). New Englishes. Ibadan: Mosuro Publishers.

Banjo, A. (1981). "The Future of World Language in Africa". Cited in Jowitt, D.( 2005). Nigerian English usage: An introduction (3rd edition). Ikeja: Longman Nigeria Plc. 
Bialystok, E. (2004). The impact of bilingualism on language and literacy development. In K. Bhatia \& W.C. Ritchie (Eds.) The handbook of bilingualism. (pp. 577-601). Malden ,MA: Blackwell Publishing.

Brown, D. (1997). Principles of language learning and language teaching. Englewood Cliffs: Prentice Hall.

Colin, B. \& Jone, S. P. (1998). Encyclopedia of bilingualism and bilingual education. Clevendon: Multilingual Matter.

Cummins, J. (1984). Bilingualism and special education issues in assessment and pedagogy. San Diego: College - Hill press.

Cummins, J. (1994). "The Acquisition of English as a Second Language.” In Spangenberg - Urbschat, K. and Pritchard, R. (Eds.) Reading instruction for ESL students (pp. 108-110). Delaware: International Reading Association.

Cummins, J. (2000). Language, power and pedagogy: Bilingual children in the crossfire. Clevedon: Multilingual Matters Ltd.

Fishman, A. J. (1980). Bilingualism and biculturism as individual and societal phenomena. Journal of Multilingualism and Multicultural Development. 1/1:3-15. http://dx.doi.org/10.1080/01434632.1980.9993995

Jowitt, D. (1991). Nigerian English usage: An introduction (3rd Edition). Ikeja: Longman.

Kembo, S. and Webb, V. (Eds.) (2000). African voices: An introduction to the languages and linguistics of Africa. Oxford: Oxford University Press.

Krashen, S. (1998). Bilingual education work. [Online] Available: http://www.rethinkingschools.org/specialreports/bilingual/Bil52.shtml. (June 4, 2010).

Obanya, P. (1992). Language issues in basic education and literacy conference paper. Hambury, UNESCO Institute of Education.

Oyetade, S.O. (2003). Language planning in a multi-ethnic state: The majority/minority dichotomy in Nigeria. Nordic Journal of African Studies 12/1:105-117.

Peal, E. and Lambert, W. (1962). The relationship between bilingualism and intelligence. Psychological Monographs, 76(27), 1-23. http://dx.doi.org/10.1037/h0093840

Romaine, S. (1994). Bilingualism. (2nd Edition). London: Blackwell Publishers.

Schemied, J. (1991). English in Africa: An introduction. London: Longman.

Skutnabb-Kangas, T. (1981). Bilingualism or not: The education of minorities. Clevendon: Multilingual Matters.

Tomori, O. (1981). Motivations for learning English in Nigeria”. In Banjo, A. et al. (Ed.). West African studies in modern language teaching and research (pp. 10-24). Ibadan: The Caxton press Ltd.

Table 1. Bilinguals and Monolinguals in the pass region for 8 terms

\begin{tabular}{|l|l|l|l|}
\hline Session & Terms & Bilinguals & Monolinguals \\
\hline \multirow{3}{*}{$2007 / 08$} & $1^{\text {st }}$ & $91.7 \%$ & $63.6 \%$ \\
\cline { 2 - 4 } & $2^{\text {nd }}$ & $91.7 \%$ & $66.7 \%$ \\
\cline { 2 - 4 } & $3^{\text {rd }}$ & $80 \%$ & $60 \%$ \\
\hline \multirow{2}{*}{$2008 / 09$} & $1^{\text {st }}$ & $91.7 \%$ & $58.4 \%$ \\
\cline { 2 - 4 } & $2^{\text {nd }}$ & $83.3 \%$ & $71.7 \%$ \\
\cline { 2 - 4 } & $3^{\text {rd }}$ & $83.3 \%$ & $73.7 \%$ \\
\hline $2009 / 10$ & $1^{\text {st }}$ & $83.4 \%$ & $75 \%$ \\
\cline { 2 - 4 } & $2^{\text {nd }}$ & $91.7 \%$ & $76.6 \%$ \\
\hline \multicolumn{2}{|l}{ Total Average } & $87.1 \%$ & $68.4 \%$ \\
\hline
\end{tabular}


Table 2. Bilinguals and Monolinguals in the fail region for 8 terms

\section{APPENDIX A}

\begin{tabular}{|l|l|l|l|}
\hline Session & Terms & Bilinguals & Monolinguals \\
\hline \multirow{3}{*}{$2007 / 08$} & $1^{\text {st }}$ & $8.3 \%$ & $36.4 \%$ \\
\cline { 2 - 4 } & $2^{\text {nd }}$ & $8.3 \%$ & $33.3 \%$ \\
\cline { 2 - 4 } & $3^{\text {rd }}$ & $20 \%$ & $40 \%$ \\
\hline $2008 / 09$ & $1^{\text {st }}$ & $8.3 \%$ & $41.6 \%$ \\
\cline { 2 - 4 } & $2^{\text {nd }}$ & $16.7 \%$ & $28.3 \%$ \\
\cline { 2 - 4 } & $3^{\text {rd }}$ & $16.7 \%$ & $26.3 \%$ \\
\hline \multirow{2}{*}{$2009 / 10$} & $1^{\text {st }}$ & $16.6 \%$ & $25 \%$ \\
\cline { 2 - 4 } & $2^{\text {nd }}$ & $8.3 \%$ & $23.4 \%$ \\
\hline \multicolumn{2}{|l}{ Total Average } & $12.9 \%$ & $31.6 \%$ \\
\hline
\end{tabular}

\section{THE QUESTIONS PREPARED FOR THE INTERVIEW SESSIONS BETWEEN THE RESEARCHER AND THE STUDENTS - SECOND LANGUAGE (L2) LEARNERS. THE INTERVIEW WAS CONDUCTED IN YORUBA LANGUAGE THEREFORE THE QUESTIONS ARE DRAFTED IN YORUBA}

So nipa ara re.[Introduce yourself]

Ede melo ni o le so?

Ede wo ni o koko gbo ti o sin n so, ede Geesi (English) tabi ede Yoruba?

Ewo ninu ede wonyii ni o rorun fun o lati lo nigba ti o ba $\mathrm{n}$ ba awon eniyan soro?

Nje awon obi re kan-an nipa fun o lati so ede Geesi nikan ninu ile?

Nje e ni omo-odo ninu ile? Bi beeni ede wo ni omo-odo yii maa n so pelu re.

Bawo ni awon obi re se maa nwa ni ile si. Iru ise wo ni won n se?

Iru ede wo ni o maa n so ninu ile tabi ni agbegbe ti o yato si ayika ile-iwe re, ede Geesi tabi ede Yoruba?

Irufe ise wo ni o wa lokan re lati se ni ojo iwaju ati pe ki ni idii ti o fi yan irufe ise naa ni aayo?

Ki ni ipa ti siso ede kan tabi meji re nko ninu eko re paapaa julo bi o se n se si ninu ede Geesi?

Nje awon oluko re $\mathrm{n}$ ko awon ede mejeeji- ede Geesi ati ede Yoruba ti a n so nipa won yii daradara?

Nje o lero pe bi o se gbo ti o si n so ede kan tabi meji yii le ran o lowo lati se daradara ninu eko ede Geesi?

Nje o feran ile-iwe re? Bi beeni tabi bee ko, kini idi re?

Ki ni akojopo idanwo yin ninu ede Geesi maa n dale ni ipele meta eko kan-an-kan ti o wa ninu saa eko kan?

Note: $\square$ talicized words/expressions are code-mixed words/expressions.

Asterisked (*) $\square$ ords/expression are ungrammatical words/expressions.
Keys to rating
$\mathrm{A}(\mathrm{A} 1)$
$=75$ and above

$\mathrm{B}(\mathrm{B} 2, \mathrm{~B} 3)=65-74$

$\mathrm{C}(\mathrm{C} 4, \mathrm{C} 5, \mathrm{C} 6)=50-64$

$\mathrm{D}(\mathrm{D} 7) \quad=45-49$

$\mathrm{E}(\mathrm{E} 8) \quad=40-44$

F( F9) $\quad=39$ and below

The scores of each of these students -bilinguals and monolinguals cannot be shown because their report cards consist of seven or eight other subjects apart from English making up complete results for the term. The school authorities believe that given out these report cards probably to make photocopies means given out the complete termly results of the students. Therefore, the score and grade of each of them were only copied out of the report card for each term. 


\section{APPENDIX B}

\section{EXTRACTS FROM THE INTERVIEW SESSIONS BETWEEN THE RESEARCHER/INTERVIEWER AND THE STUDENTS/ SECOND LANGUAGE (L2) LEARNERS}

\section{TEXT A}

The researcher with a male students with high degree of proficiency in Yoruba who is also proud and happy being a bilingual.

Researcher: Ba wo ni o?

Student: Daadaa ni ma.

Researcher: Kini o le so fun mi nipa ara re?

Student: Oruko mi ni Tindehunto Oluwatobi mo wa ni SS 3. Mo je omo bibi Ipinle Eko ni orile- ede Nigeria. Ojo ketadinlogbon osu karun-un odun 1996 ni a bi mi. Mo feran iresi ati obe igbin.

Researcher: Ede wo ni o koko mo o so?

Student: Ede Yoruba ni o, nitori pe, ohun ni awon obi mi maa $\mathrm{n}$ ba wa so ninu ile. Beeni won ko fi ipa mu mi lati so ede Geesi, sugbon mo gbo ede Geesi daradara.

Researcher: Ise wo ni awon obi re $\mathrm{n}$ se?

Student: Baba mi $\mathrm{n}$ sise nile ifowopamo kan, sugbon iya mi $\mathrm{n}$ taja niwaju ile wa, gbogbo igba ni won si maa nwa ni ile Researcher: Mo ri wipe o ni anfaani ede meji - ede Geesi ati ede Yoruba, $\mathrm{n}$ je o ro pe eyi yoo ni ipa rere lori eko re, paapaa ninu ede Geesi?

Student: Anfaani nla ni o je fun mi nitori pe awon koko ise kan wa ti won ti ko wa ninu ede Yoruba, ti oluko wa ba $\mathrm{n}$ ko wa ni iru koko ise kan-naa ninu ede Geesi, o maa n ye mi daradara.

Researcher: Jowo fun mi ni apere koko ise kan ti o je anfaani re bayi.

Student: Sileebu ninu ede Yoruba ni mo koko ni imo re, nigba ti oluko wa fun ede Geesi ko wa bi o tile je pe spelling e yato "syllable", sugbon okan naa ni koko inu won.

Researcher: O seun gan-an Tobi, ki wa ni imoran ti o ni fun awon akeeko elegbe e re?

Student: Gegebi akeeko ki won koju mo eko won, ki won fi eti si imoran oluko ati awon agba, ki won le di eni giga. 


\section{APPENDIX C}

\section{TEXT J}

The researcher with a female student, Afolabi Damilola, who understands little Yoruba but cannot express herself (speak) at all in the Yoruba language.

Researcher: Ki ni oruko re?

Student: Afolabi Damilola.

Researcher: So nipa ara re fun mi.

Student: Please ma, let me say it in English.

Researcher: Rara o, se bi omo Yoruba lo je, ba mi so ede Yoruba

Student: I can't speak Yoruba (she becomes sad, nervous, tends to cry and anxious to be excused).

Note: At this juncture, the researcher switches to English to calm and re-assure her that it is not too late to learn the Yoruba language.

Researcher: Dammy, which state(s) are your parents from?

Student: (Sighed) My parents are from Ondo State.

Researcher: What are their occupations?

Student: My father is an account while my mother is a teacher.

Researcher: Are you interested in learning Yoruba Language?

Student: Yes Ma. I want to be relating with my friends. I want to belong to their group discussions.

Researcher: Can you explain why your parents frown at speaking the Yoruba language in your house?

Student I don't know Ma, I grew up speaking English Language, though, now they want us to be speaking Yoruba Language but we can't. I can only speak it in my mind.

Researcher: Do you mean that your siblings too cannot speak Yoruba Language?

Student: No, they can't, but my brother can speak it.

Researcher: But you are being brought up by the same parent under the same roof?

Student: Ehm, my brother goes out to play football with his friends, maybe he learns through them. But my mummy does not allow me to go to neighbours' houses.

Researcher: What effect does this have on your performance in English language?

Student: (Silence)

Researcher: Dammy, I am listening.

Student: I don't know ma, but I am not happy. 